\title{
ESTIMATION OF SELECTION ACCURACY AND RESPONSES OF THE PRODUCTION CHARACTERISTICS USING DIFFERENT SELECTION INTENSITY IN MAGELANG DUCK
}

\author{
D. Purwantini, Ismoyowati and S. A. Santosa \\ Faculty of Animal Science, University of Jenderal Soedirman, \\ Jl. Dr. Soeparno No. 60, Purwokerto 53122 - Indonesia \\ Corresponding E-mail: dattadewi2002@yahoo.com
}

Received April 22, 2016; Accepted May 13, 2016

\begin{abstract}
ABSTRAK
Penelitian bertujuan untuk menduga respon dan kecermatan seleksi karakteristik bobot tetas, pertumbuhan dan produksi telur menggunakan intensitas seleksi yang berbeda pada itik Magelang. Materi penelitian adalah itik Magelang sebanyak 408 ekor terdiri atas 8 ekor pejantan, 40 ekor induk dan 360 ekor keturunannya. Metode penelitian yang digunakan adalah eksperimen dengan rancangan percobaan pola tersarang, pejantan sebagai perlakuan, induk sebagai sub perlakuan, anak sebagai ulangan dan karakteristik produktif sebagai pengamatan. Sembilan ekor day old duck (dod) dari setiap induk diukur bobot tetas dan pertumbuhannya sampai umur 8 minggu. Produksi telur yang diukur adalah Hen Day Production (HDP) pada periode peneluran awal selama 90 hari. Hasil penelitian menunjukkan bahwa dengan menggunakan intensitas seleksi berbeda $(25,50$ dan 75 persen) diperoleh respon per generasi pada karakteristik bobot tetas masing-masing 2,968; 1,870 dan $0,982 \mathrm{~g}$; karakteristik pertumbuhan masing-masing 0,$00221 ; 0,00139$ dan 0,00073 g sedangkan produksi telur masing-masing 1,$728 ; 1,088$ dan $0,571 \%$. Kecermatan seleksi untuk karakteristik bobot tetas, pertumbuhan dan poduksi telur masing-masing 0,70 0,76 dan 0,51. Berdasarkan hasil penelitian dapat disimpulkan bahwa semakin sedikit proporsi induk yang dipertahankan maka semakin tinggi nilai intensitas seleksinya, se hingga respon seleksi yang diperoleh juga semakin tinggi. Kecermatan seleksi pada karakteristik produktif ditentukan oleh nilai heritabilitasnya.

Kata kunci: Respon seleksi, intensitas seleksi, kecermatan seleksi, karakteristik produksi, itik Magelang
\end{abstract}

\begin{abstract}
This research was aimed to estimate selection response and accuracy of hatching weight, growth and egg production using different selection intensities in Magelang duck. A nested design was used in this study with experimental material was Magelang duck consisted of 8 male (treatments), 40 female (sub-treatments) and 360 offspring (replicates) and the observed parameter was productive characteristics. Nine DOD from each female were measured for hatching weight and growth up to 8 weeks old. The measured Hen Day Production (HDP) at initial laying for within days. Result showed that different selection intensities $(25,50$ and $75 \%)$ led to response in $2.968 ; 1.870$ and $0.982 \mathrm{~g}$ hatching weight; respectively; $0.00221,0.00139$ and $0.00073 \mathrm{~g}$ growth, respectively; and 1.728, 1.088 and $0.571 \%$ egg production, respectively. Selection accuracy for hatching weight, growth and egg production was $0.70,0.76$ and 0.51 , respectively. Conclusively, the less preserved female proportion, the higher selection intensity value thus the higher selection response. Selection accuracy of production
\end{abstract}


characteristics was based on its heritability value.

Keywords: selection responses, selection intensity, selection productivity, production characteristics, Magelang duck

\section{INTRODUCTION}

In some Asian countries like China (Pingel, 2009), Vietnam (Dat et al., 2008 and Cheng et al., 2009), Bangladesh (Hossain et al., 2005), Cambodia (Dinesh et al., 2009), Thailand (Tokrishna et al., 2009) and Indonesia (Pangemanan et al., 2014), duck is a prominent commodity specifically in cattle farming and economic agriculture in general (Adzitey and Adzitey, 2011). Duck farming in Indonesia has become government's concern to raise the population and production performance as the increased demand of animal protein in form of meat, egg and milk. The aim was to increase duck population in 2010-2014 from 37,950,686 to $43,902,389$, meat production from 28,554 to 33,032 ton, and egg production from $1,506,836$ to $1,791,609$ ton. The accomplished target of increased quality and quantity was by optimizing the existing local resources (Directorate General Ministry of Agriculture and Animal Health, 2011). Magelang duck is local duck mainly bred and developed in Magelang and the surrounding area with 200-600 meter above sea level (masl) altitude or located in cool upland. Government has declared Magelang duck as Magelang duck family in Decree of Minister of Agriculture 70/kpts/PD.410/2/2013 (Department of Farming and Fishery (Peterikan) of Magelang Regency, Central Java, 2013). High body immune that enables duck to accommodate different temperate areas makes Magelang duck preferred among duck growers. Magelang duck body shape is generally wider and bulky than other local duck. Purwantini et al. (2015) reported that Magelang duck has higher body weight during initial production than Tegal duck, 1,612.18 $\pm 122.74 \mathrm{~g}$ and $1,392.74 \pm 117.99 \mathrm{~g}$, respectively. Magelang ducks also have more varied plume colors, 11 as reported (Purwantini et al. 2013).

Duck breeding is important conducted in Indonesia to improve the duck's genetic quality for future genetic or germ plasm resources of local duck in Indonesia. Improving quantity and quality of the offspring is basically through genetic improvement by selecting the best male and female from the group then conducting purposive mating or crossbreeding to produce more excellent offspring than the parents (Lin et al., 2014). The selected characters are following economic concern, namely weight, egg amount, color and index, fertility, hatching weight and hatchability (Sari et al., 2011). The objective of selection is to increase the desired gene frequency in population and to decrease the unwanted gene frequency (Addisu et al., 2013)

Selection is based on high phenotypic value and breeding value (Falconer, 1983). Improving genetic quality is by estimating breeding value affected by heritability value $\left(\mathrm{h}^{2}\right)$ and the difference between the mean of selected parents with the average population of the generation (Warwick et al., 1995). Selection success is observed from the improved production particularly the responses and selection accuracy. Selection responses (R) is the improving ducks' genetic, often symbolized as $\Delta \mathrm{G}$ where change $(\Delta)$ occurred in genetic value $(G)$. selection responses and accuracy depend on selection intensity, genetic structure within population, and selection environment (Reddy, 1996). Selection intensity is the deferential selection stated in standard deviation (Hardjosubroto, 1994), therefore the value relies on the available amount if individuals as population for selection and variation.

Hatching weight, growth and egg production are quantitative expression that occur according to genetic and environmental factor. The productive characteristics may serve as the important selection criteria for superior genetic duck considering duck's high contribution to meet nutrition need in society particularly national meat and egg production. Growth rate and increasing egg production are conducted by selecting individuals with growth rate and egg production above average.

To date, only few publications are made on responses estimation and selection accuracy of productive characteristics with different selection intensity in Magelang duck, therefore this research is aimed to investigate the existing selection success. In accordance with government program to optimize the available local resources by improving the quantity and quality, a research was conducted to estimate the responses and selection accuracy of hatching weight and growth 
using different selection intensity in Magelang duck.

\section{MATERIALS AND METHOD}

Research assigned 408 Magelang duck comprising 8 males, 40 females and 360 offspring to record the lineage, hatching weight, body weight up to 8 weeks old and daily egg production. The observed ducks were kept under similar maintenance. Composition and nutrient content for starter feed to grower are presented in Table 1.

Starter feed was given measuredly adlibitum, while in grower the four-week-old ducks was given $100 \mathrm{~g}$ feed then increased to $150 \mathrm{~g}$ at eight weeks old. In production phase, feed was given $160 \mathrm{~g} / \mathrm{duck} /$ day and water was provided ad libitum. Biyatmoko (2014) reported that estimated energy requirements $(\mathrm{ME})$ and crude protein $(\mathrm{CP})$ of Alabio layer ducks at 7 months old was based on measurements on feed consumption, average weight gain (AWG), body weight (BW) and egg weight. Metabolizable energy (ME) requirement on production phase of Alabio layer duck was $2652,43 \mathrm{kcal} \mathrm{kg}$ and crude protein was $19.47 \%$. The crude protein content in this study was higher than the recommended 18\% NRC (2004).

A nested design was used for the experimental method where male duck was variable, female was sub-variable, offspring was replicates and productive characteristics as the observed variables (Becker, 1992). Female was randomly mated with male within population. Nine DOD from each mother was measured for hatching weight and growth for 8 weeks. Hen Day Production was measured at early hatching for 90 days, and the amount of egg based on individual production record was divided by total days and multiplied by 100 percent (Ahmad et al., 2010).

Statistical model was as follows:

$$
\mathrm{Y}_{\mathrm{ijk}}=\mu+\mathrm{P}_{\mathrm{i}}+\mathrm{I}\left(\mathrm{P}_{\mathrm{i}}\right)_{\mathrm{j}}+\mathrm{E}_{\mathrm{ijk}}(\text { Becker, 1992) }
$$

$\mathrm{Y}_{\mathrm{ijk}}=$ the $\mathrm{k}$ result of production characteristics measurement from the $\mathrm{j}$ female to the i male

$\mu \quad=$ mean of population

$\mathrm{P}_{\mathrm{i}}=$ effect from the $\mathrm{i}$ male

$\mathrm{I}\left(\mathrm{P}_{\mathrm{i}}\right)_{\mathrm{j}}=$ effect from the $\mathrm{j}$ female on the $\mathrm{i}$ male

$\mathrm{E}_{\mathrm{ijk}}=$ random effect or measure error on the $\mathrm{k}$ production characteristic from the $\mathrm{j}$ female to the $\mathrm{i}$ male

Relative growth rate calculation was following Brody (1945) in Arifah et al. (2013):

$$
\mathrm{LPR}=\frac{\left(\mathrm{w}_{2}-\mathrm{w}_{1}\right) /\left(\mathrm{t}_{2}-\mathrm{t}_{1}\right)}{\frac{1}{2}\left(\mathrm{w}_{2}+\mathrm{w}_{1}\right)}
$$

where :

LPR $=$ Relative Growth Rate

$\mathrm{w}_{1}=$ hatching weight

$\mathrm{w}_{2}=8$-week-old body weight

$\mathrm{t}_{1} \quad=$ time gain $\mathrm{w} 1$

$\mathrm{t}_{2} \quad$ = time gain of $\mathrm{w} 2$

Heritability value of hatching weight and growth, $0.49 \pm 0.073$ and $0.58 \pm 0.032$, respectively, was according to Purwantini et al. (2014). Heretability value of egg production obtained from analysis of variance on male and female variable was $0.27 \pm 0.035$.

Performance test in selection was performed to test the individual producibility under equal breeding maintenance. Duck's individual producibility compared to individual BV estimated from one production record using path coefficient diagram (Figure 1)

Individual Breeding value (BV):

$$
\mathrm{BV}=\mathrm{h}^{2}(\mathrm{P}-\overline{\mathrm{P}})
$$

where:

$\mathrm{h}^{2}=$ heritability of production characteristics

$\mathrm{P}=$ individual production characteristics

$\overline{\mathrm{P}}=$ mean of population production characteristics

Each individual's BV was estimated and ranked to determine the selected and the eliminated ones from the population. Estimated selection responses was obtained before the selected individual was determined, but the proportion or selection intensity from the individuals preserved in population. Selection responses was calculated according to Warwick et al. (1995) and Hardjosubroto (1994).

Selection responses value per generation is following the equation:

$$
\mathrm{R}=\mathrm{h}^{2} \cdot \mathrm{i} \cdot \sigma_{\mathrm{P}}
$$

where :

$\mathrm{R}=$ selection responses per generation

$\mathrm{h}^{2}=$ heritability value of characteristics

$\mathrm{i}=$ selection intensity

$\sigma_{\mathrm{P}}=$ standard deviation of individual characteristics within population

The remaining female proportion was 25,50 and $75 \%$ of population or 10,20 and 30 ducks respectively.

Selection accuracy for one production record $=$ $\sqrt{\mathrm{h}^{2}}$ 
Table 1. Composition and Nutrient Content for Starter feed to Grower and Layer

\begin{tabular}{lccc}
\hline \multicolumn{1}{c}{ Feed } & Starter Feed & Grower Feed & Layer Feed \\
\hline Corn & BR 1 & 47.0 & 35.0 \\
Fishmeal & & 8.0 & 10.0 \\
Rice bran & & 37.0 & 45.0 \\
Meat bone meal & & 5.0 & 7.0 \\
Milled corn cobs & & 2.0 & 2.0 \\
Premix & & 1.0 & 1.0 \\
Total & & 100 & 100 \\
Feed nutrient content: & 21 & & \\
Crude protein (\%) & 3000 & 15.068 & 16.95 \\
ME (kcal/kg) & 5 & 2806.425 & 2.844 \\
Crude fiber (\%) & 5 & 7.042 & 7.86 \\
Crude fat $(\%)$ & 1 & 4.322 & 8.07 \\
Ca (\%) & 0.9 & 1.805 & 0.56 \\
P (\%) & & 1.221 & 0.97 \\
\hline
\end{tabular}

Source: Calculation based on NRC ( 2004) and proximate (2015)

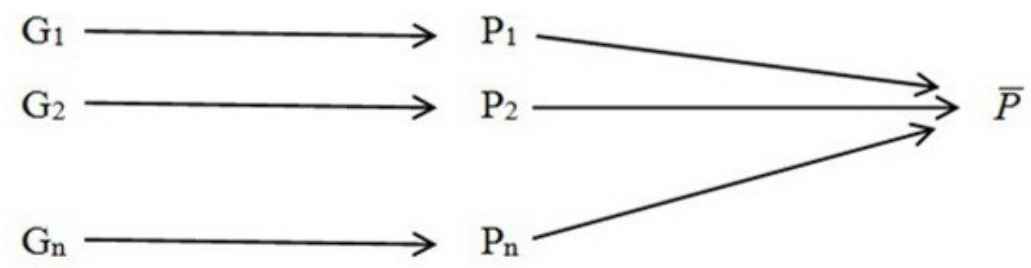

Figure 1. Path coefficient diagram. $\mathrm{G}_{1}=$ The $1^{\text {st }}$ individual; $\mathrm{G}_{\mathrm{n}}=$ The $\mathrm{n}$ individual $(\mathrm{n}=1,2$, ..n), $\mathrm{P}_{1}=$ The $1^{\text {st }}$ individual production characteristics; $\mathrm{P}_{\mathrm{n}}=$ The $\mathrm{n}$ individual production characteristics $(\mathrm{n}=1$, $2, \ldots \ldots \ldots . . . n) ; \bar{P}=$ mean of population production characteristics

\section{RESULTS AND DISCUSSION}

\section{Production Performance of Magelang Duck}

Mean and standard deviation of egg weight, hatching weight, growth up to 8 weeks old, and egg production of Magelang duck are presented in Table 2.

According to Onbasilar et al. (2011) some contributing factor to production characteristics were environment, genetic, nutrition and production cycle. Further, egg weight and quality were attributed to age and production cycle. Table 2 shows that the obtained hatching weight was higher than $36.37 \pm 3.89 \mathrm{~g}$ of $65.32 \pm 3.81 \mathrm{~g}$ egg weight of South Sumatran Pegagan duck (Sari et al., 2011) and relatively smaller than $70.84 \pm 7.82$ $\mathrm{g}$ of Chinese native duck (Xue et al., 2013). Mojosari duck's egg weight was $60.83 \mathrm{~g}$ (Yulianti et al. 2015). Dewanti et al. (2014) reported that mean hatching weight of local duck was 38.59 to $46.44 \mathrm{~g}$ from $53-60 \mathrm{~g}$ and $69-76 \mathrm{~g}$ egg weight, respectively, and Magelang duck was $41.7 \pm 3.09$ 
Table 2. Mean and Standard Deviation of Egg Weight, Hatching Weight, Growth up to 8 Weeks Old, and Egg Production of Magelang Duck

\begin{tabular}{lrc}
\hline \multicolumn{1}{c}{ Characteristics } & \multicolumn{2}{c}{$\begin{array}{c}\text { Mean and Standard } \\
\text { Deviation }\end{array}$} \\
\hline Egg weight $(\mathrm{g})$ & $65.34 \pm 4.89$ \\
Hatching weight $(\mathrm{g})$ & $43.07 \pm 4.77$ \\
8 week old weight $(\mathrm{g})$ & $1277.10 \pm 164.76$ \\
Growth (g) & $0.234 \pm 0.003$ \\
Egg production (\%) & $58.69 \pm 5.04$ \\
\hline
\end{tabular}

g (Lestari et al., 2013). Body weight of 4 and 10 week old male local duck was $349.68 \pm 46.92 \mathrm{~g}$ and $1021.23 \pm 45.50 \mathrm{~g}$, respectively, with $0.17 \pm$ 0.013 relative growth (Arifah et al., 2013). Mean and standard deviation of hatching weight, 8week-old weight and relative growth of Magelang duck was $47.34 \pm 2.29 \mathrm{~g} ; 876.70 \pm 43.28 \mathrm{~g}$ and $0.22 \pm 0.007$, respectively.

Several research on the egg production of native duck and the crossbred in Indonesia have been reported. Annual production of crossbred Mojosari-Alabio (MA) ducks was $69.4 \%$, the herded ducks was only $26.9-41.3 \%$, and the confined ducks was 55.6\% (Ketaren dan Prasetyo, 2000). Egg production of molting crossbred Alabio-Pekin (AP) and Pekin-Alabio (PA) was $52.36-71.13 \%$ and $60.21-79.47 \%$, respectively (Susanti et al., 2012), while in Philippine mallard duck with black, brown, dark brown and light brown plume was 83.96, 76.68, 77.51 and $74.76 \%$, respectively (Datuin and Magpantay, 2013). Different result was assumedly due to different species, population size, time and venue of measurement.

In this research, environmental factors $\left(\mathrm{V}_{\mathrm{E}}\right)$ were equal feed, breeding and maintenance. The uncontrollable environmental factors, sex and the male had no significant effective; therefore, the phenotypic characteristics, hatching weight, growth and egg production of Magelang duck showed genetic variation $\left(\mathrm{V}_{\mathrm{P}}=\mathrm{V}_{\mathrm{G}}\right)$. Analysis of variance result showed that female significantly affected hatching weight, growth and egg production in Magelang duck, therefore effective selection was expected to conduct on female.

\section{Selection Responses of Magelang Duck}

Selection was performed by production test method or individual record upon comparing individual production (female) based on $\mathrm{BV}$ of individual hatching weight, growth and egg production estimated from one production record. Hardjosubroto (1994) claimed that individual selection was based on individual production record that was important to trace the characteristics measured in both sexes pre-adult or on the first pre-mating.

The chosen or preserved female for the next generation was based on selection criteria or characteristics and proportion or selection intensity applied. The rank of Magelang duck based on BV of hatching weight, growth and egg production are presented in Table 3.

Table 3. shows that individual rank was based on characteristics $\mathrm{BV}$, and therefore different across individuals and characteristics. Accordingly, the chosen or preserved individuals for the next generation depended on the applied characteristics.

The increased selection result on the next offspring was indicated from the extent of selection responses. Selection responses was determined by heritability $\left(\mathrm{h}^{2}\right)$, selection intensity (i) and standard deviation of population $\left(\sigma_{\mathrm{P}}\right)$. Hatching weight $h^{2}\left(h^{2}{ }_{\text {BT }}\right)$, growth $\left(h^{2}{ }_{\text {РввH }}\right)$, and egg production $h^{2}$ was $0.49 ; 0.58$ and 0.27 , respectively, while selection intensity was determined by the preserved female proportion (\%). Population standard deviation of hatching weight $\left(\sigma_{\mathrm{PBT}}\right)$, growth $\left(\sigma_{\mathrm{PPBBH}}\right)$ and egg production $\left(\sigma_{\mathrm{PP}}\right) 4.77 \mathrm{~g}, 0.003 \mathrm{~g}$ and $5.04 \%$, respectively.

Assigning equal $\mathrm{h}^{2}$ value and standard deviation and different selection intensity resulted in different selection responses. Result based on selection estimation is presented in Table 4. Table 4 shows that the less preserved female proportion, the more selection intensity and naturally the selection responses. The preserved female proportion was 25,50 and $75 \%$, so the selected female was rank No 1 to 10,1 to 20 and 1 to 30 . Accordingly, selection responses would improve by lowering the preserved female proportion. This research was the initial stage on selecting female duck to be the ascendant to produce excellent offspring that will be the next ascendant.

\section{Selection Accuracy of Magelang Duck}

Selection accuracy or the level of correlation between selection basic criteria and individual BV 
Table 3. Rank of Magelang Duck based on Breeding Value of Hatching Weight, Growth and Egg Production

\begin{tabular}{|c|c|c|c|c|c|c|}
\hline Rank & Female TAG & $\begin{array}{l}\text { Hatching } \\
\text { Weight NP }\end{array}$ & Female TAG & Growth NP & Female TAG & $\begin{array}{c}\text { Egg Production } \\
\text { NP }\end{array}$ \\
\hline 1 & M4.4 & 2.5676 & M4.3 & 0.001839448 & M8.4 & 9.6537 \\
\hline 2 & M8.3 & 2.5676 & M3.4 & 0.001831748 & M4.4 & 9.0537 \\
\hline 3 & M1.5 & 2.0776 & M4.2 & 0.001803933 & M1.3 & 7.5537 \\
\hline 4 & M3.1 & 1.0976 & M2.3 & 0.001712266 & M6.2 & 6.9537 \\
\hline 5 & M6.4 & 1.0976 & M5.3 & 0.001672234 & M1.2 & 6.3537 \\
\hline 6 & M7.1 & 1.0976 & M7.2 & 0.001554567 & M2.1 & 6.3537 \\
\hline 7 & M7.3 & 1.0976 & M3.3 & 0.001437301 & M4.1 & 6.3537 \\
\hline 8 & M8.1 & 1.0976 & M3.5 & 0.001370888 & M8.1 & 6.0537 \\
\hline 9 & M6.3 & 0.6076 & M7.4 & 0.001328924 & M2.2 & 5.4537 \\
\hline 10 & M6.5 & 0.6076 & M8.3 & 0.001284847 & M4.2 & 5.1537 \\
\hline 11 & M1.1 & 0.1176 & M6.4 & 0.001227024 & M1.5 & 3.6537 \\
\hline 12 & M4.5 & 0.1176 & M1.1 & 0.001099747 & M5.3 & 3.0537 \\
\hline 13 & M5.1 & 0.1176 & M1.3 & 0.00109275 & M2.5 & 2.7537 \\
\hline 14 & M5.4 & 0.1176 & M7.5 & 0.001062624 & M1.4 & 2.1537 \\
\hline 15 & M6.2 & 0.1176 & M1.2 & 0.000975631 & M3.5 & 1.8537 \\
\hline 16 & M8.5 & 0.1176 & M8.2 & 0.000845597 & M4.5 & 1.8537 \\
\hline 17 & M1.4 & -0.3724 & M2.2 & 0.000767985 & M5.5 & 1.8537 \\
\hline 18 & M2.1 & -0.3724 & M3.1 & 0.000617181 & M7.2 & 1.5537 \\
\hline 19 & M2.5 & -0.3724 & M2.4 & 0.000615094 & M7.5 & 1.5537 \\
\hline 20 & M3.2 & -0.3724 & M6.1 & 0.000549998 & M2.4 & 1.2537 \\
\hline 21 & M3.3 & -0.3724 & M5.1 & 0.000336637 & M1.1 & 0.9537 \\
\hline 22 & M4.1 & -0.3724 & M1.4 & 0.000297705 & M7.4 & 0.3537 \\
\hline 23 & M7.2 & -0.3724 & M5.2 & 0.000294167 & M8.3 & 0.3537 \\
\hline 24 & M3.4 & -0.8624 & M8.4 & 0.00020622 & M3.3 & -0.5463 \\
\hline 25 & M1.2 & -1.3524 & M4.1 & 0.000103775 & M2.3 & -0.8463 \\
\hline 26 & M6.1 & -1.3524 & M6.3 & $4.24886 \mathrm{E}-05$ & M5.1 & -1.7463 \\
\hline 27 & M7.4 & -1.3524 & M2.1 & $4.18441 \mathrm{E}-05$ & M8.5 & -1.7463 \\
\hline 28 & M2.3 & -1.8424 & M8.1 & $1.03998 \mathrm{E}-05$ & M3.4 & -2.0463 \\
\hline 29 & M2.4 & -1.8424 & M1.5 & $-1.88063 \mathrm{E}-05$ & M7.1 & -2.0463 \\
\hline 30 & M4.3 & -1.8424 & M8.5 & -0.000123095 & M6.5 & -2.3463 \\
\hline 31 & M5.3 & -1.8424 & M5.4 & -0.000130112 & M8.2 & -2.9463 \\
\hline 32 & M5.5 & -1.8424 & M7.3 & -0.000271077 & M5.2 & -3.2463 \\
\hline 33 & M1.3 & -2.3324 & M3.2 & -0.00033333 & M6.1 & -3.2463 \\
\hline 34 & M2.2 & -2.3324 & M2.5 & -0.000432021 & M7.3 & -3.2463 \\
\hline 35 & M3.5 & -2.3324 & M6.2 & -0.000487498 & M4.3 & -3.8463 \\
\hline 36 & M4.2 & -2.3324 & M4.4 & -0.000694635 & M6.3 & -3.8463 \\
\hline 37 & M5.2 & -2.3324 & M5.5 & -0.0007741 & M3.2 & -4.1463 \\
\hline 38 & M8.4 & -2.3324 & M6.5 & -0.001264834 & M3.1 & -4.4463 \\
\hline 39 & M8.2 & -2.8224 & M4.5 & -0.001345738 & M6.4 & -5.0463 \\
\hline 40 & M7.5 & -3.3124 & M7.1 & -0.001958209 & M5.4 & -5.3463 \\
\hline
\end{tabular}

$\mathrm{BV}=$ Breeding Value 
Tabel 4. Estimated Selection Responses with Different Selection Intensity on Hatching Weight, Growth and Egg Production of Magelang Duck

\begin{tabular}{|c|c|c|c|c|c|}
\hline \multirow{3}{*}{$\begin{array}{l}\text { Preserved } \\
\text { Female } \\
\text { Proportion } \\
(\%)\end{array}$} & \multirow{3}{*}{$\begin{array}{l}\text { Preserved } \\
\text { Female } \\
\text { Rank }\end{array}$} & \multirow{3}{*}{$\begin{array}{c}\text { Selection } \\
\text { Intensity (i) }\end{array}$} & \multicolumn{3}{|c|}{ Selection Responses on Characteristics } \\
\hline & & & $\begin{array}{l}\text { Hatching Weight } \\
\text { (g) }\end{array}$ & $\begin{array}{c}\text { Growth } \\
\text { (g) }\end{array}$ & $\begin{array}{c}\text { Egg Production } \\
(\%)\end{array}$ \\
\hline & & & $\left(\mathrm{h}_{\mathrm{BT}}^{2} \cdot \mathrm{i} \cdot \sigma_{\mathrm{PBT}}\right)$ & $\left(\mathrm{h}_{\mathrm{PBBH}}^{2} \cdot \mathrm{i} \cdot \sigma_{\mathrm{PPBBH}}\right)$ & $\left(\mathrm{h}_{\mathrm{P}}^{2} \cdot \mathrm{i} \cdot \sigma_{\mathrm{PP}}\right)$ \\
\hline 25 & $1-10$ & 1.27 & 2.968 & 0.00221 & 1.728 \\
\hline 50 & $1-20$ & 0.80 & 1.870 & 0.00139 & 1.088 \\
\hline 75 & $1-30$ & 0.42 & 0.982 & 0.00073 & 0.571 \\
\hline
\end{tabular}

$\mathrm{h}_{\mathrm{BT}}^{2}=$ hatching weight heritability; $\sigma_{\mathrm{PBT}}=$ standard deviation oh hatching weight; $\mathrm{h}_{\mathrm{PBBH}}^{2}=$ growth heritability; $\sigma_{\mathrm{PPBBH}}=$ standard deviation of growth; $\mathrm{h}_{\mathrm{P}}^{2}=$ egg production heritability; $\sigma_{\mathrm{PP}}=$ standard deviation of egg production; $i=$ selection intensity

of the selected characteristics for one production record was stated in formula $\sqrt{\mathrm{h}^{2}}$. This value is important in breeding ducks because the higher accuracy value the higher expected responses. Selection accuracy value higher than $55 \%$ belongs to high category (Warwick et al., 1995). Accuracy value of hatching weight, growth and egg production of Magelang duck was $0.70 ; 0.76$ and 0.51 and included in medium to high category. Accordingly, hatching weight, growth and egg production of Magelang duck were effective for selection.

\section{CONCLUSION}

The more mother proportion preserved, the higher selection intensity so the selection responses or result is bigger. Different productive characteristics show different selection accuracy based on heritability value. Hatching weight and growth are considered as selection criteria in breeding of Magelang duck.

\section{ACKNOWLEDGEMENT}

Sincerest gratitude goes to Directorate General of Higher Education, Ministry of Research, Technology and Higher Education through Research Centre and Community Service Jenderal Soedirman University for funding the Competitive Grant and contract no. 1135/UN23.14/PN.01.00/2015

\section{REFERENCES}

Addisu H. M. Hailu and W. Zewdu. 2013. Indigenous Chicken Production System and Breeding Practice in North Wollo, Amhara Region, Ethiopia. Poult Fish Wildl Sci. 1 (2): 108-111.

Adzitey, F and S.P. Adzitey. 2011. Duck Production: Has a Potential to Reduce Povertyamong Rural Households in Asian Communities-A Review. J. World's Poult. Res. 1(1): 7-10.

Ahmad, F., A. Haq, M. Ashraf, J. Hussain and M. Z. Siddiqui. 2010. Production Performance of White Leghorn Hens Under Different Lighting Regimes. Pakistan Vet. J. 30(1): 21-24.

Arifah, N. Ismoyowati and N. Iriyanti. 2013. Tingkat Pertumbuhan dan Konversi Pakan pada berbagai Itik Lokal Jantan (Anas Plathyrhinchos) dan Itik Manila Jantan (Cairrina moschata ). Jurnal Ilmiah Peternakan. 1(2):718 - 725.

Becker, W.A. 1992. Manual Quantitative Genetics. Eight ${ }^{\text {th }}$ Edition. Student Book Corporation. Washington.

Brody, S., 1945. Bioenergetics and Growth. Reinhold Pub.Corp., New York Page 18.

Biyatmoko, D. 2014. Production increase of alabio duck by predicting real nutrients needs on crude proteins and metabolizable energy in feed. Int. J. Biosci. 5(3): 82-87. 
Cheng, Y.S. Rouvier, R. Liu, H.L. Huang, S.C. Huang, Y.C. Liao, C.W. Tai, J.J.L. Tai, C and J. P. Poivey. 2009. Eleven generations of selection for the duration of fertility in the intergeneric crossbreeding of ducks. Genet. Sel. Evol. 41(1): 32-35.

Dat, N. H., V.T. Hung, H.X. Tung and V.C. Thien. 2008. Production of crossbreed Ri Vang with Ai Cap breed. J. Anim. Sci. Tech. 10(1): 37- 44 .

Datuin, J. R.M. and V. A. Magpantay. 2013. Henday egg production and egg qualities of philippine mallard duck (Anas platyrhynchos domesticus L.) with varying plumage colors. Philipp. J. Vet. Anim. Sci. 39 (2): 211-218.

Dewanti, R. Yuhan and Sudiyono. 2014. Pengaruh Bobot dan Frekuensi Pemutaran Telur terhadap Fertilitas, Daya Tetas dan Bobot Tetas Itik Lokal. Buletin Peternakan. 38(1): 16-20.

Department of Farming and Fishery (Peterikan) Magelang Regency, Central Java, 2013. Bebek Kalung, Potensi Besar Itik Magelang. Livestockreview.com, Bisnis. (www.livestockreview.com > news >. 14 September 2014)

Dinesh, M.T., J. Sölkner, M. Wurzinger, S. Thea E. Geerlings and O. Thieme. 2009. Characterization of domestic duck production systems in Cambodia. AHBL Promoting strategies for prevention and control of HPAI. Rome

Directorate General Ministry of Agriculture and Animal Health. 2011. The Strategis Plan. Secretary of Directorate General Ministry of Agriculture and Animal Health 20102014.

Falconer, D. S. 1993. Introduction to quantitative genetics. John Wiley and Son, Inc., New York.

Hardjosubroto, W. 1994. Aplikasi Pemuliabiakan Ternak di Lapangan. Grasindo, Jakarta.

Hossain, S. T. H. Sugimoto, G. J. U. Ahmed and M. R. Islam. 2005. Effect of integrated rice duck farming on rice yield, farm productivity, and rice-provisioning ability of farmers. Asian Journal of Agriculture and Development. 1(2):79-86.

Ketaren, P.P. and L.H. Prasetyo. 2000. Produktivitas itik silang MA di Ciawi dan Cirebon. Pros. Seminar Nasional Peternakan dan Veteriner. Cisarua - Bogor, 18 - 19 September 2000. Puslit Peternakan,
Bogor. p $198-205$.

Lestari, E. Ismoyowati and Sukardi. 2013. Korelasi antara Bobot Telur dengan Bobot Tetas dan Perbedaan Susut Bobot pada Telur Entok (Cairrina moschata) dan Itik (Anas plathyrhinchos). Jurnal Ilmiah Peternakan. 1 (1):163-169.

Lin, R. L. H. P. Chen, R. Rouvier and J. P. Poivey. 2014. Selection and Crossbreeding in Relation to Plumage Color Inheritance in Three Chinese Egg Type Duck Breeds (Anas Platyrhynchos). Asian-Australas. J. Anim. Sci. 27(8): 1069-1074.

National Research Council (NRC). 2004. Nutrient requirement of poultry. Washington DC, National Academy Press

Onbasilar, E.E., E. Erdem, O. Poynaz and S. Yalcin, 2011. Effects of hen production cycle and egg weight on egg quality and composition, hatchability, duckling quality and first-week body weight in Pekin ducks. Poult. Sci. 90: 2642 - 2647

Pangemanan, S. P., B. Hartono, S. Devadoss, L. W. Sondakh and B. Ali. 2014. Economic analysis of traditional duck farmer's household in Minahasa Regency North Sulawesi, Indonesia. Livestock Research for Rural Development. 26(7):136-139.

Pingel, H. 2009. Waterfowl production for food security; Conference at the 4th World Waterfowl conference; Thrissur, India.. p. 6.

Purwantini, D., T. Yuwanta, T. Hartatik and Ismoyowati. 2013. Morphology and Genetic Diversity of Mitochondrial DNA D-Loop Region Using PCR-RFLP Analysis in Magelang Duck and Other Native Duck. J. Indonesian Trop. Anim. Agric. 38 (1): 1-9.

Purwantini, D., R.S. S Santosa dan Ismoyowati. 2014. Penaksiran Parameter Genetik Karakteristik Bobot Tetas Dan Pertumbuhan Itik Magelang. Prosiding Seminar Nasional Teknologi dan Agribisnis Peternakan untuk Akselerasi Pemenuhan Pangan Hewani (Seri II). Fakultas Peternakan. Universitas Jenderal Soedirman. 14 Juni 2014: 429-433

Purwantini, D., Ismoyowati and S. A. Santosa, 2015. Production and reproduction characteristics of Tegal and Magelang ducks. Proceedings of The 5th International Conference on Sustainable Animal Agriculture for Developing Countries (SAADC 2015) October 27-30, 2015. Dusit Thani Pattaya Hotel, Thailand: 61-63

Reddy R.P. 1996. Symposium: The Effect of 
Long-Term Selection on Growth of Poultry. Poult. Sci. 75: 1164-1167.

Sari, M. L. Ronny, R. N. Peni, S. H and N. Chairun, N. 2011. Keragaan Telur Tetas Itik Pegagan (Hatching egg performans of Pegagan duck. JSPI 6 (2): $97-102$.

Susanti, T., R.R. Noor, P.S. Hardjosworo dan L.H. Prasetyo. 2012. Relationship of molting trait and egg production on crossbred Peking and Alabio ducks. J. Ilmu Ternak Vet. 17(2):112-119.

Tokrishna, R. 2009. Integrated Livestock-Fish Farming Systems In Thailand. Department of Agricultural and Resource Economics.
Kasetsart University, Bangkok, Thailand. Warwick, E.J., M. Astuti and W. Hardjosubroto. 1995. Pemuliaan Ternak. Gadjah Mada University Press, Yogyakarta

Xue, D.B., S.J. Zhou, Z.J.Bing, G.W. Li, W. Yun and C.X. Ying. 2013. Principal component analysis on egg quality characteristics of native duck breeds in China J. Anim. Vet. Sci. 12 (15): 1286-1288.

Yulianti, D. L, P. Trisunuwati, O. Sjofjan and E. Widodo. 2015. Effect of andrographis paniculata a phytobiotic on consumption, feed conversion and Mojosari duck egg production. Int. J Poult. Sci. 14(9): 529-532. 